\title{
Serum levels of chemokines CCL4 and CCL5 in cirrhotic patients indicate the presence of hepatocellular carcinoma
}

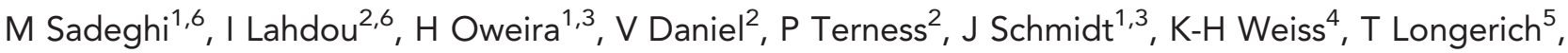 \\ P Schemmer ${ }^{1}$, G Opelz ${ }^{2}$ and A Mehrabi ${ }^{*}, 1$ \\ ${ }^{1}$ Department of General, Visceral and Transplant Surgery, University of Heidelberg, Heidelberg, Germany; ${ }^{2}$ Department of \\ Transplantation Immunology, University of Heidelberg, Heidelberg, Germany; ${ }^{3}$ Vascular and Visceral Surgery, Zürich Surgical \\ Center, Kappelistr. 7, Zürich CH-8002, Switzerland; ${ }^{4}$ Department of Internal Medicine IV, University of Heidelberg, Heidelberg, \\ Germany and ${ }^{5}$ Department of Pathology, University of Heidelberg, Heidelberg, Germany
}

Background: Most hepatocellular carcinomas (HCCs) are diagnosed at an advanced stage. The prognostic value of serum tumour markers alpha-fetoprotein (AFP) and des-gamma-carboxy prothrombin (DCP) is limited. The aim of our study is to evaluate the diagnostic value of serum growth factors, apoptotic and inflammatory mediators of cirrhotic patients with and without HCC.

Methods: Serum samples were collected from cirrhotic potential liver transplant patients (LTX) with $(n=61)$ and without HCC $(n=78)$ as well as from healthy controls (HCs; $n=39$ ). Serum concentrations of CRP, neopterin and IL-6 as markers of inflammation and thrombopoietin (TPO), GCSF, FGF basic and VEGF, HMGB1, CK-18 (M65) and CK18 fragment (M30) and a panel of proinflammatory chemokines (CCL2, CCL3, CCL4, CCL5, CXCL5 and IL-8) were measured. Chi square, Fisher exact, Mann-Whitney U-tests, ROC curve analysis and forward stepwise logistic regression analyses were applied.

Results: Patients with HCC had higher serum TPO and chemokines ( $P<0.001$ for TPO, CCL4, CCL5 and CXCL5) and lower CCL2 $(P=0.008)$ levels than cirrhotic patients without HCC. Multivariate forward stepwise regression analysis for significant parameters showed that among the studied parameters CCL4 and CCL5 $(P=0.001)$ are diagnostic markers of HCC. Serum levels of TPO and chemokines were lower, whereas M30 was significantly higher in cirrhotic patients than in HCs.

Conclusions: High serum levels of inflammatory chemokines such as CCL4 and CCL5 in the serum of cirrhotic patients indicate the presence of HCC.

Hepatocellular carcinoma (HCC) invariably develops within a setting of chronic inflammation caused by hepatotropic viruses, toxins, metabolic liver disease or autoimmunity (Alison et al, 2011). HCC is the sixth most prevalent cancer and the third most frequent cause of cancer-related death. Prevention, diagnosis and treatment of HCC are of great concern. Fine-needle biopsy or other investigations such as computed tomography, magnetic resonance imaging or digital subtraction angiography were used as the gold standard diagnosis in HCC (D'Onofrio et al, 2008; Bruix et al, 2011; Rahbari et al, 2011).

The prognosis at early stages relies on tumour status, liver function and the applied treatment. Tumour status is defined by so-called BCLC Classification (Arii et al, 2000; Llovet et al, 2003). Early HCC diagnosis is essential, as only in early stages (BCLC A) the tumour is curable by resection, LTx or ablation therapy. Patients with small solitary tumours (single lesion $<5 \mathrm{~cm}$ ) and

*Correspondence: Dr A Mehrabi; E-mail: arianeb.mehrabil@med.uni-heidelberg.de
${ }^{6}$ These authors contributed equally to this work.

revised 3 March 2015; accepted 13 May 2015; published online 13 August 2015

(c) 2015 Cancer Research UK. All rights reserved 0007-0920/15 
very well preserved liver function are the best candidates for liver resection or transplantation. LTx is most beneficial for individuals who are poor candidates for resection due to cirrhosis as the underlying disease (Forner et al, 2012).

Screening of the serum tumour marker alpha-fetoprotein (AFP) and imaging with ultrasound (US) every 6 months in patients with liver cirrhosis have been recommended to detect HCC at earlier stages amenable to effective treatment strategies (Spangenberg et al, 2006). Serum AFP is the most widely used marker for HCC. However, its sensitivity and specificity for HCC is poor and varies with the cutoff value, ethnicity of the patient, etiology of liver disease and tumour stage (Spangenberg et al, 2006; Toro et al, 2014). The sensitivity of AFP decreases from $52 \%$ to $25 \%$ when tumour diameter is $>3$ and $<3 \mathrm{~cm}$, respectively (Bertino et al, 2012). Besides AFP, AFP lectin fraction 3 (AFP-L3) and DCP are widely used clinically as serum tumour markers of HCC. These serum biomarkers (AFP, DCP and AFP-L3) are not accurate enough for the early diagnosis of HCC (Bertino et al, 2010, 2012).

Association of immune parameters such as apoptosis markers CK18 (M65) and CK18 fragment (M30), chemokines CCR2, CXCR2, CXCR4, CCL2, CCL4, CCL5, CCL11, CCL15, CCL17, CCL22, CXCL1, CXCL5, CXCL6, CXCL8, CXCL10, CXCL12, CXCL14, Chromogranin A and high-mobility-group-protein B1 (HMGB1) with cirrhosis and HCC have been studied previously in patients with end-stage liver diseases (ESLD; Nahon et al, 2008; Dominguez et al, 2009; Charni et al, 2011; Lavallard et al, 2011; Nakamoto et al, 2011; Tacke et al, 2011; Biondi et al, 2012; Bertran et al, 2013; Li et al, 2013; Waidmann et al, 2013; Wang et al, 2013; Yan et al, 2013; Cao et al, 2014; Hefetz-Sela et al, 2014; Shi et al, 2014).

Development of new reliable serological biomarkers for early stages of HCC is needed to improve clinical diagnosis and outcomes. Furthermore, the marker should be sensitive, easily measurable, reproducible and minimally invasive.

Our aim in the present study is to assess the diagnostic value of cell death markers HMGB1, M65 and M30, growth factors TPO, GCSF, FGF basic and VEGF and inflammatory chemokines CCL2 (monocyte chemoattractant protein-1), CCL3 (macrophage inflammatory protein-1), CCL4 (macrophage inflammatory protein-1beta), CCL5 (RANTES) and CXCL5 (epithelial cell-derived neutrophil-activating peptide-78) and IL-8 (CXCL8) for early detection of HCC in cirrhotic patients (Le et al, 2004).

\section{MATERIALS AND METHODS}

Patients. The following parameters were measured in 139 cirrhotic patients (aged 52.0 \pm 11.2 years, 32 female, 61 cirrhotic $\mathrm{HCC}+$ and 78 cirrhotic $\mathrm{HCC}-$ ) who underwent deceased donor LTx between January 2008 and April 2011. HCC diagnosis was confirmed by pathological reports. Original liver diseases were chronic viral hepatitis $\mathrm{C}$ and/or B in 40 patients, alcohol abuse in 41 , congenital or autoimmune disease, including cryptogenic cirrhosis, biliary disease, metabolic liver disease, autoimmune hepatitis and amyloidosis, in 58 patients. Preoperative and demographic parameters, including age, gender, severity of liver diseases (determined by MELD score), bilirubin, INR, albumin, viral infection statuses such as $\mathrm{CMV}, \mathrm{HBV}$ and $\mathrm{HCV}$ IgG, retransplantation, serum levels of CRP and neopterin as inflammatory markers and serum levels of cell death markers M65 and M30, TPO, CCL2, CCL3, CCL4, CCL5 CXCL5 and CXCL8 (IL-8), were analysed. We examined the association between HCC with mentioned parameters. Thirty-nine healthy volunteers (HCs) served as controls to establish references for studied parameters such as cytokines and chemokines. Controls were free of infectious and other inflammatory illnesses. The study was approved by the local Ethical Committee.
Serum separation. Serum separator tubes were centrifuged at 4000 r.p.m. for $15 \mathrm{~min}$ at $4{ }^{\circ} \mathrm{C}$. Serum was collected after the blood clotting process. Serum was snap frozen within $2 \mathrm{~h}$, after the blood was drawn and stored at $-30{ }^{\circ} \mathrm{C}$ until testing. All serum samples were thawed only once before testing.

Determination of serum immune parameters. Cell apoptotic marker (M30; CK18 fragment), growth factors thrombopoietin (TPO) and chemokines C-X-C motif ligand 5 (ENA-78, CXCL5), $\mathrm{C}-\mathrm{C}$ motif ligand 2 (MCP-1, CCL2), macrophage inflammatory protein-1a (MIP-1a, CCL3), macrophage inflammatory protein-1b (MIP-1b, CCL4) and regulated upon activation normal $\mathrm{T}$ cell expressed and secreted (RANTES, CCL5) were measured by ELISA using the Quantikine Kits (R\&D Systems, Wiesbaden, Germany).

Statistical analyses. Categorical and continuous variables were analysed using chi square, Fisher exact and Mann-Whitney $U$ tests. Continuous variables were modelled stratifying by median. Correlation between variables was analysed using Spearman's rank correlation coefficient. The most sensitive cutoff values were calculated by receiver operating curve (ROC) curve analysis. Univariable and multivariable forward stepwise logistic regression analyses were applied and identified the greatest association of parameters with HCC. All statistical analyses were performed with the Statistical Package for the Social Sciences (SPSS, 18.0; SPSS Inc., Chicago, IL, USA). After Bonferroni correction, $P$ values $\leqslant 0.05$ were defined as statistically significant.

\section{RESULTS}

Immune parameters in cirrhotic patients with different original liver diseases. Serum levels of M30, TPO, GCSF, FGF basic and VEGF, CXCL5, IL-8, CCL2, CCL3, CCL4 and CCL5 were similar among patients with virus-, alcohol- or congenital/autoimmuneinduced cirrhosis (data not shown).

All cirrhotic patients (HCC + and $\mathrm{HCC}-$ ) vs healthy controls. Serum levels of HMGB1 $\left(3.2 \pm 6.7 \mathrm{pg} \mathrm{ml}^{-1}\right.$ vs $\left.3.7 \pm 2.7: P=0.006\right)$, TPO $\left(208 \pm 237 \mathrm{pg} \mathrm{ml}^{-1}\right.$ vs $\left.505 \pm 106: \quad P<0.0001\right), \quad$ VEGF $\left(35 \pm 49 \mathrm{pg} \mathrm{ml}^{-1}\right.$ vs $\left.87 \pm 52: P<0.0001\right)$, CCL2 $\left(194 \pm 533 \mathrm{pg} \mathrm{ml}^{-1}\right.$ vs 179 $\pm 71: P=0.0001)$, CCL3 $\left(33 \pm 280 \mathrm{pg} \mathrm{ml}^{-1}\right.$ vs $70 \pm 199$ : $P=0.002), \quad$ CCL5 $\left(2.7 \pm 5.2 \mathrm{mg} \mathrm{ml}^{-1}\right.$ vs $\left.11 \pm 11: \quad P<0.0001\right)$ and CXCL5 $\quad\left(167 \pm 238 \mathrm{pg} \mathrm{ml}^{-1} \quad\right.$ vs $\left.766 \pm 540: \quad P<0.0001\right)$ were lower, whereas serum CRP $\left(20.0 \pm 24.7 \mathrm{mgl}^{-1}\right.$ vs $3.5 \pm 6.1$ : $P<0.0001)$, neopterin $\left(49.2 \pm 69.1 \mathrm{nmoll}^{-1}\right.$ vs $6.4 \pm 3.2$ : $P<0.0001)$, IL-6 $\left(74.0 \pm 435 \mathrm{pg} \mathrm{ml}^{-1}\right.$ vs $\left.0.0 \pm 0.0: P<0.0001\right)$, IL-8 $\quad\left(40.5 \pm 87.3 \mathrm{pg} \mathrm{ml}^{-1}\right.$ vs $\left.11.5 \pm 26.1: \quad P=0.014\right), \quad$ M65 $\left(2349 \pm 1127 \mathrm{pg} \mathrm{ml}^{-1}\right.$ vs $\left.358 \pm 111: \quad P<0.0001\right)$ and M30 $\left(1195 \pm 839 \mathrm{pg} \mathrm{ml}^{-1}\right.$ vs $\left.185 \pm 133: P<0.0001\right)$ were significantly higher in cirrhotic patients than in 39 healthy controls (16 females, age: mean \pm s.d. $39.6 \pm 10.0$ years). The results suggest a decreased chemokine expression and an increased rate of apoptosis and inflammation in cirrhotic patients. Serum levels of GCSF $(P=0.08)$ and FGF basic $(P=0.11)$ were similar in patients and healthy controls.

Cirrhotic patients with HCC vs cirrhotic patients without HCC. HCC patients with cirrhosis were older, had more HCV + and lower MELD score (11.8 \pm 5.0 vs $22.4 \pm 8.6: P<0.001)$, CRP $\left(15.8 \pm 21.8 \mathrm{mgl}^{-1}\right.$ vs $\left.22.9 \pm 26.1: \quad P=0.009\right)$ and neopterin $\left(22.2 \pm 21.0 \mathrm{nmoll}^{-1}\right.$ vs $\left.58.1 \pm 76.8: P<0.001\right)$ than cirrhotic patients without HCC - (Table 1). AFP test was carried out in 102 cirrhotic patients; 23 of $49 \mathrm{HCC}+$ and 9 of $53 \mathrm{HCC}-$ patients had positive results $(P<0.0001)$. Serum levels of TPO $\left(226 \pm 210 \mathrm{pg} \mathrm{ml}^{-1}\right.$ vs $\left.163 \pm 247: P<0.001\right)$ and chemokines CCL4 $\left(170 \pm 378 \mathrm{pg} \mathrm{ml}^{-1}\right.$ vs $\left.101 \pm 483: P<0.0001\right)$, CCL5 $\left(3.6 \pm 5.5\right.$ vs $\left.2.0 \pm 4.5 \mathrm{ng} \mathrm{ml}^{-1}: P<0.0001\right)$ and CXCL5 $\left(230 \pm 301\right.$ vs $118 \pm 159 \mathrm{pg} \mathrm{ml}^{-1}$ : $\left.P<0.001\right)$ were higher, 
Table 1. Demographic and characteristic data of cirrhotic patient groups

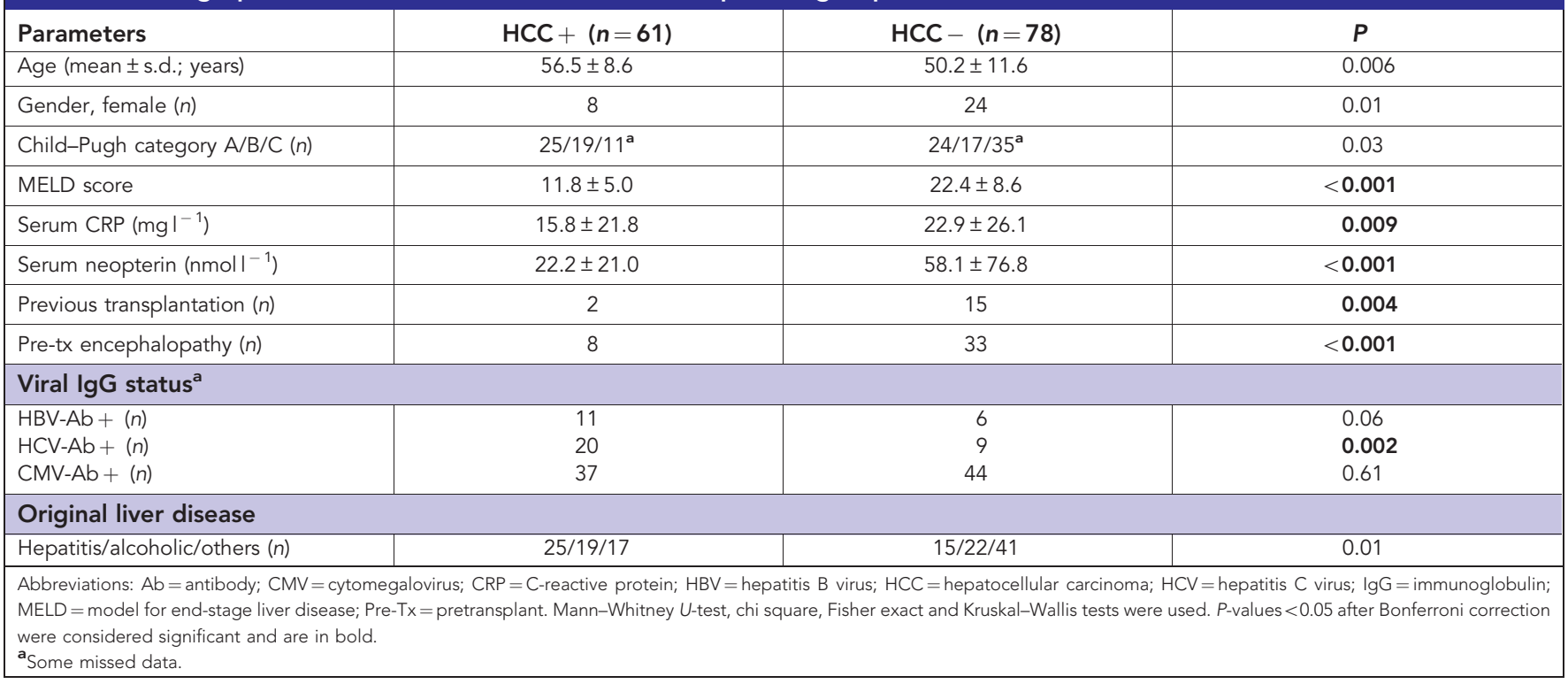

\section{Table 2. Immune responses and laboratory data of patient groups}

\begin{tabular}{|c|c|c|c|c|}
\hline Parameters (mean \pm s.d.) (n) & $\mathrm{HCs}(n=39)$ & $\mathrm{HCC}-(n=78)$ & $\mathrm{HCC}+(n=61)$ & $P^{\star}$ \\
\hline $\mathrm{M} 30\left(\mathrm{UI}^{-1}\right)$ & $185 \pm 133$ & $1179 \pm 856$ & $1181 \pm 870$ & 1.00 \\
\hline TPO $\left(\mathrm{pg} \mathrm{ml}^{-1}\right)$ & $501 \pm 106$ & $163 \pm 247$ & $226 \pm 210$ & $<0.001$ \\
\hline Median & 172 & 111 & 80 & \\
\hline CCL3 $\left(p g \mathrm{ml}^{-1}\right)$ & $70 \pm 199$ & $51 \pm 370$ & $10 \pm 54$ & 0.13 \\
\hline $\mathrm{CCL} 4\left(\mathrm{pg} \mathrm{ml} \mathrm{l}^{-1}\right)$ & $66 \pm 32$ & $101 \pm 484$ & $170 \pm 378$ & $<0.0001$ \\
\hline $\operatorname{CCL5}\left(\mathrm{ng} \mathrm{ml}^{-1}\right)$ & $11 \pm 11$ & $2.0 \pm 4.8$ & $3.6 \pm 5.5$ & $<0.0001$ \\
\hline CXCL5 $\left(p g \mathrm{ml}^{-1}\right)$ & $766 \pm 540$ & $118 \pm 159$ & $230 \pm 301$ & $<0.001$ \\
\hline
\end{tabular}
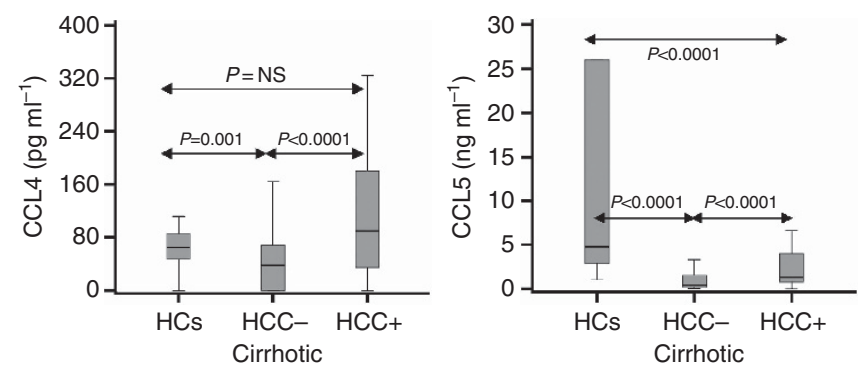

Figure 1. CCL4 and CCL5 serum levels in cirrhotic patients with and without $\mathrm{HCC}$ as well as in healthy controls (HCs).

whereas surprisingly CCL2 $\left(129 \pm 192 \mathrm{pg} \mathrm{ml}^{-1} \quad(\right.$ median $=80)$ vs $245 \pm 689$ (median =111): $P=0.008)$ was lower in $\mathrm{HCC}+$ than in HCC - cirrhotic patients (Table 2 and Figure 1). Interestingly, the apoptosis marker M30 $(P=0.60)$, M65 $(P=0.92)$, GCSF $(P=0.66)$, VEGF $(P=0.51)$ and FGF basic $(P=0.28)$ were similar in the two patient groups. The results indicate high expression of particular chemokines in HCC patients compared with cirrhotic patients without HCC.

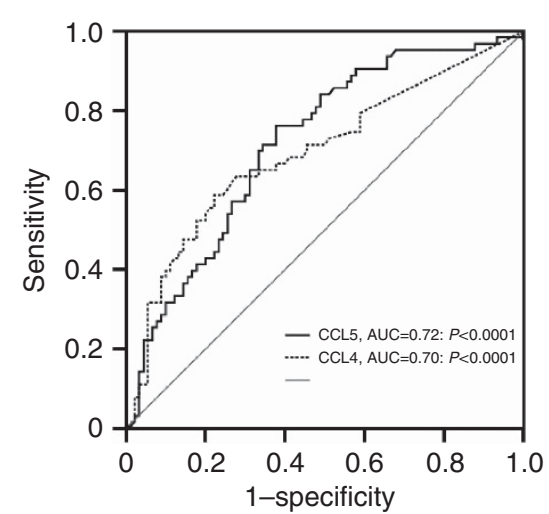

Figure 2. ROC curve analysis for calculation of diagnostic accuracy, cutoff value, sensitivity and specificity of CCL4 and CCL5 plasma levels for HCC screening in cirrhotic patients.

Sensitivity, specificity, PPV, NPV and cutoff values of parameters. To calculate sensitivities, specificities and cutoff values, we preformed ROC analysis for significant parameters. The best cutoff values were $170 \mathrm{pg}, 66 \mathrm{pg}, 0.86 \mathrm{ng}$ and $84 \mathrm{pg} \mathrm{ml}^{-1}$ for TPO, CCL4, 
CCL5 and CXCL5, respectively. The sensitivity, specificity, PPV and NPV were $69,67,59$ and $70 \%$ for TPO, 66, 74, 67 and $73 \%$ for CCL4, 71, 68, 62 and 74\% for CCL5 and 71, 63, 59 and 72\% for CXCL5, respectively (Figure 2). AFP had a sensitivity of $47 \%$, a specificity of $89 \%$, a PPV of $79 \%$ and a NPV of $64 \%$.

Logistic regression analysis for definition of HCC. Univariate regression analyses showed that $\mathrm{AFP} \geqslant 20 \mathrm{IU}$ (Odds ratio $(\mathrm{OR})=5.10$, CI 1.71-15.21: $P=0.003)$, TPO $\geqslant 170 \mathrm{pg} \mathrm{ml}^{-1} \mathrm{OR}=3.74$, CI $1.84-$ 7.60: $P<0.001), \quad$ CCL $4 \geqslant 66 \mathrm{pg} \mathrm{ml}^{-1}(\mathrm{OR}=4.10$, CI 2.00-8.36: $P=0.0001), \quad$ CXCL5 $\geqslant 84 \mathrm{pg} \mathrm{ml}^{-1} \quad(\mathrm{OR}=4.00, \quad$ CI $1.97-8.27$ : $P=0.0001)$ and CCL5 $\geqslant 0.86 \mathrm{ng} \mathrm{ml}^{-1} \quad(\mathrm{OR}=4.42$, CI 2.169.06: $P<0.0001)$ in cirrhotic patients are diagnostic markers of HCC. Multivariate forward stepwise regression analysis of significant parameters showed that, among the studied parameters, serum CCL4 $\geqslant 66 \mathrm{pg} \mathrm{ml}^{-1}(\mathrm{OR}=6.24$, CI 2.55-15.23: $P<0.0001)$, CCL5 $\geqslant 0.86 \mathrm{ng} \mathrm{ml}^{-1}(\mathrm{OR}=3.63$, CI 1.48-8.88: $P=0.004)$ and $\mathrm{AFP} \geqslant 20 \mathrm{IU}(\mathrm{OR}=5.69$, CI 1.58-20.37: $P=0.004)$ have the best association with HCC.

Correlation between HCC and variables. Spearman's rank correlation coefficient was used to calculate correlation between significant variables. HCC conversely correlated with MELD score $(r=-0.382$ : $P<0.0001)$, serum CRP $(r=-0.213: \quad P=0.009)$, neopterin $(r=-0.353: P<0.001)$ and IL-6 $(r=-0.356: P<0.0001)$ and positively with age $(r=0.401: P<0.0001)$, TPO $(r=0.316: P<0.001)$, CCL4 $(r=0.366: P<0.0001)$, CCL5 $(r=0.363: P<0.0001)$, CXCL5 $(r=0.319: P<0.001)$ and AFP $(r=0.421: P<0.0001)$.

TACE procedure, tumour size, AFP and immune parameters. TACE procedure was performed in $40 \mathrm{HCC}$ patients. MELD score, liver function tests, chemokine levels, neopterin, CRP and albumin levels were similar in patients with and without TACE and in patients with and without detectable AFP $(P=$ not significant for all investigations). Tumour size was only correlated with TPO $(r=0.41: P=0.002)$.

\section{DISCUSSION}

Association of cytokines, chemokines and apoptotic markers with ESLD. In the present study, we investigated the serum levels of biomarkers, including cytokeratin 18 (M65), cytokeratin 18 (CK18; M30) fragment, TPO, CC and CXC motif chemokines and AFP, to find a diagnostic marker for HCC. A detailed comparison of serum levels and/or production of CXCL5 and CC chemokines between healthy controls and patients with ESLD has not been performed so far. The results of our study indicate that patients with advanced fibrosis and ESLD are unable to produce sufficient chemokines, in accordance with previous studies showing low expression and production of chemokines in cirrhotic patients (Nischalke et al, 2004; Tacke et al, 2011; Zhang et al, 2014). CK18 is an apoptosis marker and a major intermediate filament protein in liver cells and a popular marker for detecting liver fibrosis in recent years (Feldstein et al, 2009; Chitturi et al, 2011; Jazwinski et al, 2012; Sumer et al, 2013). This apoptosis marker increased in sera of patients with cirrhotic liver diseases compared with healthy controls, reflecting the higher rate of apoptosis (Chitturi et al, 2011; Jazwinski et al, 2012). Chemokines - biomolecules that induce chemotaxis - have a fundamental role not only in inflammation and immune surveillance but also in cancer progression (Aldinucci et al, 2012). Chemokines are important mediators of host defense functioning in the recruitment and activation of leukocytes and other cells at the sites of injury, infection and neoplasia (Driscoll, 1994).

$\mathrm{C}-\mathrm{C}$ receptor 5 is a receptor for CCL3, CCL4 and CCL5 and is expressed in effector and effector memory subsets of Th1 CD4+ $\mathrm{T}$ cells and CD8 $+\mathrm{T}$ cells (Kang and Shin, 2011). Previous studies showed high expression of CCL4 and CCL5 chemokines in viral, alcoholic and autoimmune inflammatory diseases in the liver (Bautista, 2001; Bautista and Wang, 2001; Maghazachi, 2010; Kang and Shin, 2011). Intrahepatic and peripheral blood levels of chemokines CCL4 and CCL5 are increased during chronic hepatitis C (Larrubia et al, 2008). In patients with HCV infection intrahepatic expression of CCL4 and CCL5, especially in periportal and lobular areas is increased, and their levels of expression were significantly associated with the degree of liver inflammation (Larrubia et al, 2008). CCL4 and CCL5 expression have also been associated with liver histological activity index in chronic hepatitis C (Larrubia et al, 2008; Moura et al, 2009). CCL4 and CCL5 are potent chemoattractants for memory T lymphocytes, monocytes, NK cells and eosinophils, and they attract cells through an interaction with their receptor CCR5 (Navratilova, 2006; Maghazachi, 2010; Ingelsten et al, 2011). CCL5 was found to be highly expressed in activated T lymphocytes, macrophages, fibroblasts, platelets, mesangial cells, epithelial cells, megakaryocytes and some tumours (Navratilova, 2006; Charni et al, 2009; Takai et al, 2009; Maghazachi, 2010).

Association of soluble factors and cancer. Interaction between host cells and cancer cells happens via a large variety of soluble factors. The association of chemokines with cancer is not surprising, as they both promote and restrict tumour onset and/or progression (Gonzalez-Martin et al, 2012). CCL4 and CCL5 are expressed in human breast cancer and CCL5 is associated with the progression of particularly triple-negative (ostrogen, progesterone and tyrosine-protein kinase erbB-2 negative) breast cancer (Niwa et al, 2001; Wolf et al, 2003; Lv et al, 2013). This chemokine can regulate the function of effector cells and chemotaxis relies on its concentration. Therefore, the increased level of CCL5 can enhance its role in chemotaxis (Yoshie et al, 2001). CCL5 is minimally expressed by normal breast epithelial duct cells but is highly expressed by breast tumour cells, suggesting that this chemokine has a role in breast cancer development and/or progression (Soria and Ben-Baruch, 2008; Lapteva and Huang, 2010). Upregulation of CCL4 in human colon and gastric cancer was reported previously (Saito et al, 2003; Erreni et al, 2009). Following prostatectomy, the expression of CCL4 is associated with recurrence of prostate cancer and the absence of CCL4 expression supported recurrence-free survival after prostatectomy (Blum et al, 2008).

Correlation of C-C chemokines to HCC. HCC is the commonest primary malignant cancer of the liver in the world (Bosch et al, 2004). Some cancer staging systems, grading severity of dysfunction and tumour burden can estimate the survival of HCC patients (Hsu et al, 2010).

CCR1 binds a particular set of C-C chemokines, including CCL3, CCL4 and CCL5, and is expressed by a variety of cells, including lymphocytes, monocytes, basophils, neutrophils and bone marrow progenitor cells (Lu et al, 2003). CCR5, another specific receptor for CCL3, CCL4 and CCL5, was also detected in tumour-infiltrating lymphocytes but not in hepatoma cells (Yoong et al, 1999). Lu et al (2003) provided that hepatoma cells express CCR1 in vitro and in vivo. The correlation between CCL5 and HCC is a controversial issue (Yoshie et al, 2001), whereas an association between HCC susceptibility and genetic polymorphism of CCL5-28 and CCL5-403 was described (Yoshie et al, 2001). A study by Liu et al (1999) provides evidence of CCL5-28G mutation with increased transcription of the RANTES gene.

To our knowledge, the association of HCC with CCL4 gene expression and/or serum levels was not studied so far. Thus our report is the first study that evaluates this association. CCL4 and 


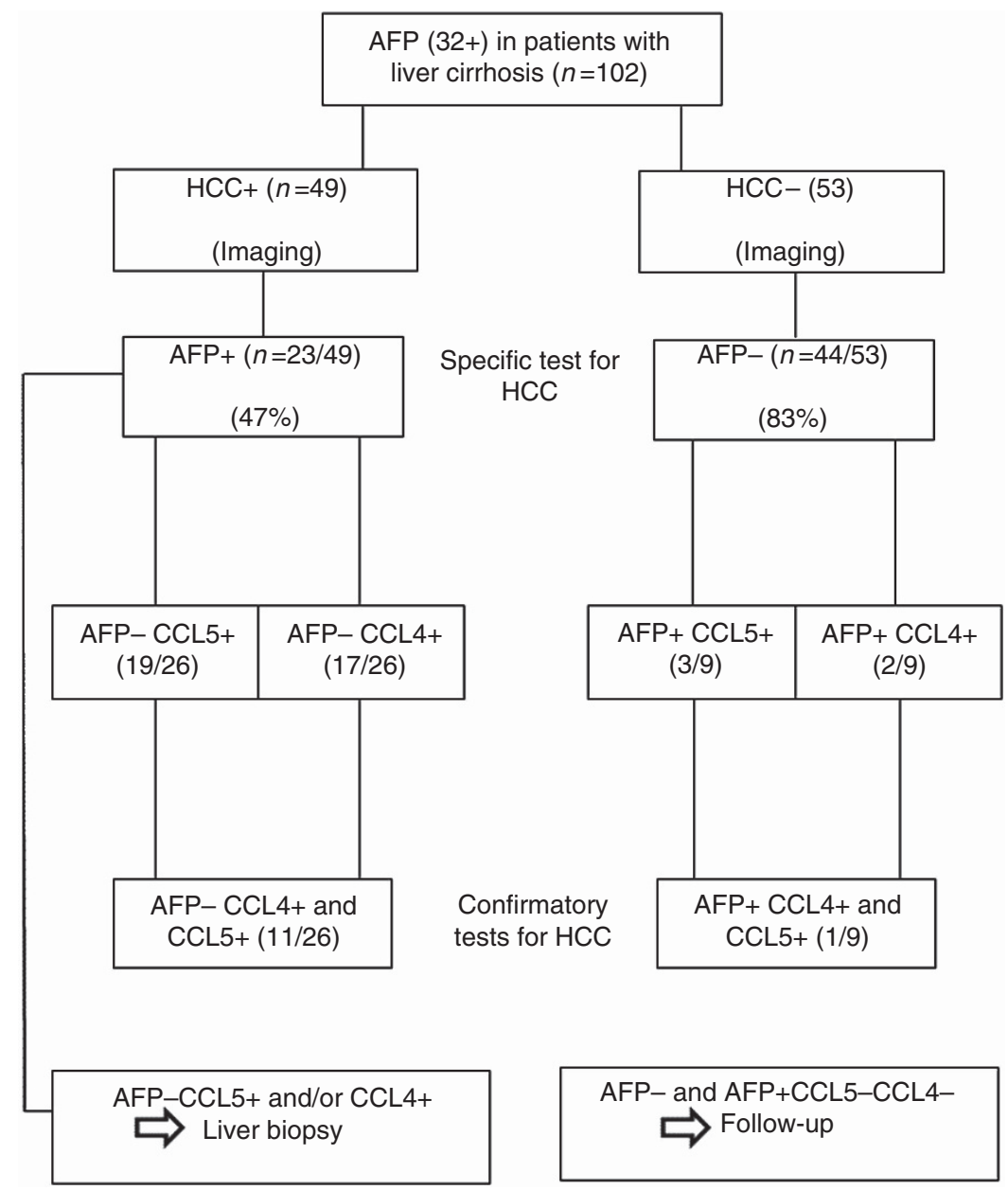

Figure 3. Algorithmic approach to AFP, CCL4 and CCL5 tests in cirrhotic patients.

CCL5 can bind to their receptors in the carcinomatous tissues and Kupffer cells in the liver and induce the infiltration of various inflammatory cells. We speculate that cirrhotic high producers of CCL4 and CCL5 are at higher risk of HCC. It can be postulated that high serum levels of CCL4 and CCL5 indicate the presence of HCC in patients with liver cirrhosis and along with other indicators can help in early detection of HCC. Algorithmic approach of our results (Figure 3 ) indicates that AFP is a specific test in patients with suspected HCC (imaging). When imaging is positive but AFP is negative, surrogate markers such CCL5 and CCL4 are confirmatory tests. We recommend a liver biopsy in patients with positive imaging and negative AFP, when CCL5 and/ or CCL4 are positive.

Furthermore, future large prospective studies may be needed to investigate the association between these chemokines and hepatocellular carcinoma. Until now, AFP together with imaging and pathology detection are commonly used in the clinical early diagnosis of liver cancer. However, the specificity and sensitivity of AFP used in screening for liver cancer are not satisfactory (Zhao et al, 2013). The results of the present study indicate that CCL4 and CCL5 are more sensitive and AFP more specific markers of HCC and that monitoring the combination of these markers might be an innovative approach in the early diagnosis of HCC.

\section{CONFLICT OF INTEREST}

The authors declare no conflict of interest.

\section{AUTHOR CONTRIBUTIONS}

Mahmoud Sadeghi designed, analysed and wrote the manuscript; Imad Lahdou assisted to design and performed the chemokines and cytokine tests. Hani Oweira operated patients and collected the serum samples. Jan Schmidt and Peter Schemmer treated the patients. Volker Daniel, Peter Terness, Karl Heinz Weiss, Thomas Longerich and Gerhard Opelz assisted in writing the manuscript. Arianeb Mehrabi treated the patients and assisted in preparing and writing the manuscript.

\section{REFERENCES}

Aldinucci D, Gloghini A, Pinto A, Colombatti A, Carbone A (2012) The role of $\mathrm{CD} 40 / \mathrm{CD} 40 \mathrm{~L}$ and interferon regulatory factor 4 in Hodgkin lymphoma microenvironment. Leuk Lymphoma 53(2): 195-201.

Alison MR, Nicholson LJ, Lin WR (2011) Chronic inflammation and hepatocellular carcinoma. Recent Results Cancer Res 185: 135-148.

Arii S, Yamaoka Y, Futagawa S, Inoue K, Kobayashi K, Kojiro M, Makuuchi M, Nakamura Y, Okita K, Yamada R (2000) Results of surgical and nonsurgical treatment for small-sized hepatocellular carcinomas: a retrospective and nationwide survey in Japan. The Liver Cancer Study Group of Japan. Hepatology 32(6): 1224-1229.

Bautista AP (2001) Acute alcohol intoxication and endotoxemia desensitize HIV-1 gp120-induced CC-chemokine production by Kupffer cells. Life Sci 68(17): 1939-1949.

Bautista AP, Wang E (2001) Chronic ethanol intoxication enhances the production of cytokine-induced neutrophil chemoattractant and 
macrophage inflammatory protein- 2 by hepatocytes after human immunodeficiency virus-1 glycoprotein 120 vaccination. Alcohol 24(1): 35-44.

Bertino G, Ardiri A, Malaguarnera M, Malaguarnera G, Bertino N, Calvagno GS (2012) Hepatocellualar carcinoma serum markers. Semin Oncol 39(4): $410-433$.

Bertino G, Ardiri AM, Calvagno GS, Bertino N, Boemi PM (2010) Prognostic and diagnostic value of des-gamma-carboxy prothrombin in liver cancer. Drug News Perspect 23(8): 498-508.

Bertran E, Crosas-Molist E, Sancho P, Caja L, Lopez-Luque J, Navarro E, Egea G, Lastra R, Serrano T, Ramos E, Fabregat I (2013) Overactivation of the TGF-beta pathway confers a mesenchymal-like phenotype and CXCR4-dependent migratory properties to liver tumor cells. Hepatology 58(6): 2032-2044.

Biondi A, Malaguarnera G, Vacante M, Berretta M, D'Agata V, Malaguarnera M, Basile F, Drago F, Bertino G (2012) Elevated serum levels of Chromogranin A in hepatocellular carcinoma. BMC Surg 12(Suppl 1): S7.

Blum DL, Koyama T, M'Koma AE, Iturregui JM, Martinez-Ferrer M, Uwamariya C, Smith Jr JA, Clark PE, Bhowmick NA (2008) Chemokine markers predict biochemical recurrence of prostate cancer following prostatectomy. Clin Cancer Res 14(23): 7790-7797.

Bosch FX, Ribes J, Diaz M, Cleries R (2004) Primary liver cancer: worldwide incidence and trends. Gastroenterology 127(5 Suppl 1): S5-S16.

Bruix J, Sherman M. American Association for the Study of Liver D (2011) Management of hepatocellular carcinoma: an update. Hepatology 53(3): 1020-1022.

Cao Z, Fu B, Deng B, Zeng Y, Wan X, Qu L (2014) Overexpression of Chemokine (C-X-C) ligand 1 (CXCL1) associated with tumor progression and poor prognosis in hepatocellular carcinoma. Cancer Cell Int 14(1): 86.

Charni F, Friand V, Haddad O, Hlawaty H, Martin L, Vassy R, Oudar O, Gattegno L, Charnaux N, Sutton A (2009) Syndecan-1 and syndecan-4 are involved in RANTES/CCL5-induced migration and invasion of human hepatoma cells. Biochim Biophys Acta 1790(10): 1314-1326.

Charni F, Sutton A, Rufat P, Laguillier C, Mansouri A, Moreau R, Ganne-Carrié N, Trinchet JC, Beaugrand M, Charnaux N, Nahon P (2011) Chemokine RANTES promoter dimorphisms and hepatocellular carcinoma occurrence in patients with alcoholic or hepatitis C virus-related cirrhosis. Cancer Epidemiol Biomarkers Prev 20(7): $1439-1446$

Chitturi S, Wong VW, Farrell G (2011) Nonalcoholic fatty liver in Asia: Firmly entrenched and rapidly gaining ground. J Gastroenterol Hepatol 26(Suppl 1): 163-172.

D’Onofrio M, Faccioli N, Zamboni G, Malago R, Caffarri S, Fattovich G, Mucelli RP (2008) Focal liver lesions in cirrhosis: value of contrastenhanced ultrasonography compared with Doppler ultrasound and alphafetoprotein levels. Radiol Med (Torino) 113(7): 978-991.

Dominguez M, Miquel R, Colmenero J, Moreno M, Garcia-Pagan JC, Bosch J, Arroyo V, Ginès P, Caballería J, Bataller R (2009) Hepatic expression of CXC chemokines predicts portal hypertension and survival in patients with alcoholic hepatitis. Gastroenterology 136(5): 1639-1650.

Driscoll KE (1994) Macrophage inflammatory proteins: biology and role in pulmonary inflammation. Exp Lung Res 20(6): 473-490.

Erreni M, Bianchi P, Laghi L, Mirolo M, Fabbri M, Locati M, Mantovani A, Allavena P (2009) Expression of chemokines and chemokine receptors in human colon cancer. Methods Enzymol 460: 105-121.

Feldstein AE, Wieckowska A, Lopez AR, Liu YC, Zein NN, McCullough AJ (2009) Cytokeratin-18 fragment levels as noninvasive biomarkers for nonalcoholic steatohepatitis: a multicenter validation study. Hepatology 50(4): 1072-1078.

Forner A, Llovet JM, Bruix J (2012) Hepatocellular carcinoma. Lancet 379(9822): 1245-1255.

Gonzalez-Martin A, Mira E, Manes S (2012) CCR5 in cancer immunotherapy: More than an "attractive" receptor for T cells. Oncoimmunology 1(1): 106-108.

Hefetz-Sela S, Stein I, Klieger Y, Porat R, Sade-Feldman M, Zreik F, Nagler A, Pappo O, Quagliata L, Dazert E, Eferl R, Terracciano L, Wagner EF, Ben-Neriah Y, Baniyash M, Pikarsky E (2014) Acquisition of an immunosuppressive protumorigenic macrophage phenotype depending on c-Jun phosphorylation. Proc Natl Acad Sci USA 111(49): 17582-17587.

Hsu CY, Hsia CY, Huang YH, Su CW, Lin HC, Lee PC, Loong CC, Chiang JH, Huo TI, Lee SD (2010) Selecting an optimal staging system for hepatocellular carcinoma: comparison of 5 currently used prognostic models. Cancer 116(12): 3006-3014.
Ingelsten $\mathrm{M}$, Karlsson-Parra A, Granqvist AB, Molne J, Olausson M, Haraldsson B, Nyström J (2011) Postischemic inflammatory response in an auxiliary liver graft predicts renal graft outcome in sensitized patients. Transplantation 91(8): 888-894.

Jazwinski AB, Thompson AJ, Clark PJ, Naggie S, Tillmann HL, Patel K (2012) Elevated serum CK18 levels in chronic hepatitis $C$ patients are associated with advanced fibrosis but not steatosis. J Viral Hepat 19(4): 278-282.

Kang W, Shin EC (2011) Clinical implications of chemokines in acute and chronic hepatitis C virus infection. Yonsei Med J 52(6): 871-878.

Lapteva N, Huang XF (2010) CCL5 as an adjuvant for cancer immunotherapy. Expert Opin Biol Ther 10(5): 725-733.

Larrubia JR, Benito-Martinez S, Calvino M, Sanz-de-Villalobos E, Parra-Cid T (2008) Role of chemokines and their receptors in viral persistence and liver damage during chronic hepatitis $\mathrm{C}$ virus infection. World $J$ Gastroenterol 14(47): 7149-7159.

Lavallard VJ, Bonnafous S, Patouraux S, Saint-Paul MC, Rousseau D, Anty R, Le Marchand-Brustel Y, Tran A, Gual P (2011) Serum markers of hepatocyte death and apoptosis are non invasive biomarkers of severe fibrosis in patients with alcoholic liver disease. PLoS One 6(3): e17599.

Le Y, Zhou Y, Iribarren P, Wang J (2004) Chemokines and chemokine receptors: their manifold roles in homeostasis and disease. Cell Mol Immunol 1(2): 95-104.

Li Y, Wu J, Zhang W, Zhang N, Guo H (2013) Identification of serum CCL15 in hepatocellular carcinoma. Br J Cancer 108(1): 99-106.

Liu H, Chao D, Nakayama EE, Taguchi H, Goto M, Xin X, Takamatsu JK, Saito H, Ishikawa Y, Akaza T, Juji T, Takebe Y, Ohishi T, Fukutake K, Maruyama Y, Yashiki S, Sonoda S, Nakamura T, Nagai Y, Iwamoto A, Shioda T (1999) Polymorphism in RANTES chemokine promoter affects HIV-1 disease progression. Proc Natl Acad Sci USA 96(8): 4581-4585.

Llovet JM, Burroughs A, Bruix J (2003) Hepatocellular carcinoma. Lancet 362(9399): 1907-1917.

Lu P, Nakamoto Y, Nemoto-Sasaki Y, Fujii C, Wang H, Hashii M, Ohmoto Y, Kaneko S, Kobayashi K, Mukaida N (2003) Potential interaction between CCR1 and its ligand, CCL3, induced by endogenously produced interleukin-1 in human hepatomas. Am J Pathol 162(4): 1249-1258.

Lv D, Zhang Y, Kim HJ, Zhang L, Ma X (2013) CCL5 as a potential immunotherapeutic target in triple-negative breast cancer. Cell Mol Immunol 10(4): 303-310.

Maghazachi AA (2010) Role of chemokines in the biology of natural killer cells. Curr Top Microbiol Immunol 341: 37-58.

Moura AS, Carmo RA, Teixeira AL, Rocha MO (2009) Soluble inflammatory markers as predictors of hepatocellular damage and therapeutic response in chronic hepatitis C. Braz J Infect Dis 13(5): 375-382.

Nahon P, Sutton A, Rufat P, Simon C, Trinchet JC, Gattegno L, Beaugrand M, Charnaux N (2008) Chemokine system polymorphisms, survival and hepatocellular carcinoma occurrence in patients with hepatitis $C$ virusrelated cirrhosis. World J Gastroenterol 14(5): 713-719.

Nakamoto Y, Mizukoshi E, Kitahara M, Arihara F, Sakai Y, Kakinoki K, Fujita Y, Marukawa Y, Arai K, Yamashita T, Mukaida N, Matsushima K, Matsui O, Kaneko S (2011) Prolonged recurrence-free survival following OK432-stimulated dendritic cell transfer into hepatocellular carcinoma during transarterial embolization. Clin Exp Immunol 163(2): 165-177.

Navratilova Z (2006) Polymorphisms in CCL2\&CCL5 chemokines/chemokine receptors genes and their association with diseases. Biomed Pap Med Fac Univ Palacky Olomouc Czech Repub 150(2): 191-204.

Nischalke HD, Nattermann J, Fischer HP, Sauerbruch T, Spengler U, Dumoulin FL (2004) Semiquantitative analysis of intrahepatic CC-chemokine mRNas in chronic hepatitis C. Mediators Inflamm 13(5-6): 357-359.

Niwa Y, Akamatsu H, Niwa H, Sumi H, Ozaki Y, Abe A (2001) Correlation of tissue and plasma RANTES levels with disease course in patients with breast or cervical cancer. Clin Cancer Res 7(2): 285-289.

Rahbari NN, Mehrabi A, Mollberg NM, Muller SA, Koch M, Buchler MW, Weitz J (2011) Hepatocellular carcinoma: current management and perspectives for the future. Ann Surg 253(3): 453-469.

Saito S, Kitayama J, Jin ZX, Tsuno N, Kaisaki S, Seto Y, Nagawa H (2003) Beta-chemokine, macrophage inflammatory protein-1beta (MIP-1beta), is highly expressed in diffuse type human gastric cancers. J Exp Clin Cancer Res 22(3): 453-459.

Shi M, Chen MS, Sekar K, Tan CK, Ooi LL, Hui KM (2014) A blood-based three-gene signature for the non-invasive detection of early human hepatocellular carcinoma. Eur J Cancer 50(5): 928-936.

Soria G, Ben-Baruch A (2008) The inflammatory chemokines CCL2 and CCL5 in breast cancer. Cancer Lett 267(2): 271-285. 
Spangenberg HC, Thimme R, Blum HE (2006) Serum markers of hepatocellular carcinoma. Semin Liver Dis 26(4): 385-390.

Sumer S, Aktug Demir N, Kolgelier S, Cagkan Inkaya A, Arpaci A, Saltuk Demir L, Ural O (2013) The clinical significance of serum apoptotic cytokeratin 18 neoepitope M30 (CK-18 M30) and matrix metalloproteinase 2 (MMP-2) levels in chronic hepatitis B patients with cirrhosis. Hepat Mon 13(6): e10106.

Tacke F, Zimmermann HW, Trautwein C, Schnabl B (2011) CXCL5 plasma levels decrease in patients with chronic liver disease. J Gastroenterol Hepatol 26(3): 523-529.

Takai H, Ashihara M, Ishiguro T, Terashima H, Watanabe T, Kato A, Suzuki M (2009) Involvement of glypican-3 in the recruitment of M2-polarized tumor-associated macrophages in hepatocellular carcinoma. Cancer Biol Ther 8(24): 2329-2338.

Toro A, Ardiri A, Mannino M, Arcerito MC, Mannino G, Palermo F, Bertino G, Di Carlo I (2014) Effect of pre- and post-treatment alphafetoprotein levels and tumor size on survival of patients with hepatocellular carcinoma treated by resection, transarterial chemoembolization or radiofrequency ablation: a retrospective study. BMC Surg 14: 40.

Waidmann O, Koberle V, Bettinger D, Trojan J, Zeuzem S, Schultheiss M, Kronenberger B, Piiper A (2013) Diagnostic and prognostic significance of cell death and macrophage activation markers in patients with hepatocellular carcinoma. J Hepatol 59(4): 769-779.

Wang W, Huang P, Zhang L, Wei J, Xie Q, Sun Q, Zhou X, Xie H, Zhou L, Zheng S (2013) Antitumor efficacy of C-X-C motif chemokine ligand 14 in hepatocellular carcinoma in vitro and in vivo. Cancer Sci 104(11): $1523-1531$.
Wolf M, Clark-Lewis I, Buri C, Langen H, Lis M, Mazzucchelli L (2003) Cathepsin D specifically cleaves the chemokines macrophage inflammatory protein-1 alpha, macrophage inflammatory protein-1 beta, and SLC that are expressed in human breast cancer. Am J Pathol 162(4): $1183-1190$.

Yan HX, Wu HP, Zhang HL, Ashton C, Tong C, Wu H, Qian QJ, Wang HY, Ying QL (2013) p53 promotes inflammation-associated hepatocarcinogenesis by inducing HMGB1 release. J Hepatol 59(4): 762-768.

Yoong KF, Afford SC, Jones R, Aujla P, Qin S, Price K, Hubscher SG, Adams DH (1999) Expression and function of CXC and CC chemokines in human malignant liver tumors: a role for human monokine induced by gamma-interferon in lymphocyte recruitment to hepatocellular carcinoma. Hepatology 30(1): 100-111.

Yoshie O, Imai T, Nomiyama H (2001) Chemokines in immunity. Adv Immunol 78: 57-110.

Zhang L, Ma D, Li X, Deng C, Shi Q, You X, Leng X, Li M, Tang F, Zhang F, Li Y (2014) Gene expression profiles of peripheral blood mononuclear cells in primary biliary cirrhosis. Clin Exp Med 14(4): 409-416.

Zhao YJ, Ju Q, Li GC (2013) Tumor markers for hepatocellular carcinoma. Mol Clin Oncol 1(4): 593-598.

This work is published under the standard license to publish agreement. After 12 months the work will become freely available and the license terms will switch to a Creative Commons AttributionNonCommercial-Share Alike 4.0 Unported License 